\title{
Manajemen Festival Musik Kampus Virtual di IAKN Manado
}

\author{
Erwin Sianturi \\ Dosen Program Studi Pendidikan Musik Gereja IAKN Manado \\ esianturi@iakn-manado.ac.id
}

\begin{abstract}
Abstrak
Situasi adaptasi kebiasaan baru pada masa pandemik Covid-19 membuat sistem kehidupan mengalami perubahan secara signifikan. Salah satunya adalah perubahan model pembelajaran di perguruan tinggi. Festival Musik Kampus Virtual yang di selenggarakan di IAKN Manado oleh mahasiswa Program Studi Pendidikan Musik Gereja semester lima tahun akademik 2020/2021 menjadi menarik untuk teliti bagaimana pengelolaan kegiatan tersebut dilakukan ditengahtengah situasi masa kebiasaan adaptasi baru saat ini. Berdasarkan permasalahan tersebut maka dirumuskan permasalahan penelitian yaitu; 1) Bagaimana pengelolaan Festival Musik Kampus Virtual di IAKN Manado 2) Apa kekurangan dan kelebihan pengelolaan Festival Musik Kampus Virtual di lakn Manado. Penelitian ini menggunakan metode kualitatif. Hasil penelitian ini adalah bahwa pengelolaan yang digunakan menggunakan metode blended methode. Proses pengelolaan mengacu pada POAC (planning, organizing, actuating, controlling). Kekurangan pada pengelolaannyan adalah keterbatasan pengelola dalam menguasai teknologi digital virtual membuat proses kerja tidak berjalan sesuai dengan perencanaan, efesiensi waktu juga berkurang. Namun kelebihan pada pengelolaan ini adalah lebih mudah menjangkau masyarakat penonton, dan menghemat biaya produksi.
\end{abstract}

Kata kunci: Manajemen, Musik, Pertunjukan, Virtual, Seni

\begin{abstract}
The situation of adapting to new habits during the Covid-19 pandemic made the living system experience significant changes. One of them is a change in the learning model in higher education. The Virtual Campus Music Festival held at IAKN Manado by students of the Church Music Education Study Program for the fifth semester of the 2020/2021 academic year is interesting to examine how the management of these activities is carried out in the midst of the current situation of the new adaptation habit. Based on these problems, the research problems were formulated, namely; 1) How is the management of the Virtual Campus Music Festival in IAKN Manado? 2) What are the advantages and disadvantages of managing the Virtual Campus Music Festival at lakn Manado? This study uses a qualitative method. The result of this research is that the management used is the blended method. The management process refers to POAC (planning, organizing, actuating, controlling). The drawback in its management is that the manager's limitations in mastering virtual digital technology make the work process not go according to plan. However, the advantages of this management are that it is easier to reach the audience, saves production costs, and provides efficient production time.
\end{abstract}

Keywords: Management, Music, Performance, Virtual, Art 


\section{Pendahuluan}

Situasi adaptasi kebiasaan baru pada masa pandemik Covid-19 membuat sistem kehidupan mengalami perubahan secara signifikan. Beberapa aspek kehidupan seperti ekonomi, gaya hidup, kesehatan, politik, hiburan, dan pendidikan mengalami tranformasi dalam kebentukan maupun sistem pengelolaannya. Salah satu profesi yang menerima dampak pandemik ini adalah para pelaku seni khususnya yang berkecimpung dalam dunia seni pertunjukan ${ }^{1}$. Pertunjukan musik terjadi kevakuman semenjak pandemik terjadi, aktivitas seni pertunjukan seolah-olah mati. Namun pada masa adaptasi kebiasaan baru ini beberapa pemerintah daerah menyarankan dunia hiburan seni mulai merambat ke dunia virtual ${ }^{2}$. Hal ini tujuannya supaya pelaku seni pertunjukan dapat bekerja namun masih tetap menjalankan peraturan pemerintah tentang protokol kesehatan adaptasi kebiasaan baru. Hal ini membuat dunia seni pertunjukan perlahan-lahan mulai bergerak menyajikan karya-karyanya melalui media virtual.

\footnotetext{
1 Sianturi, Erwin. "New Normal" : Dimensi Percepatan Menuju Peradaban Musik 4.0. Pusaka Media, Lampung, 2020.
}

Beberapa musisi profesional nasional dan internasional seperti Erwin Gutawa, Noah, Coldplay, Maroon Five pada masa kebiasaan adaptasi baru ini mulai menampilkan pertunjukan musik mereka secara virtual. Selain itu kegiatan festival musik nasional juga dihadirkan secara virtual seperti; Jong Batak Arts Festival 2020, Festival Layang Labok 2020, dan sebagainya. Hal ini menunjukkan bahwa ruang virtual menjadi pilihan satu-satunya bagi penggiat seni pertunjukan untuk tetap dapat beraktifitas. Transformasi bentuk ruang seni pertunjukan secara virtual tersebut secara otomatis akan menuntut sistem pengelolaan yang berbeda pula dari sebelumnya.

$$
\text { Festival Musik Kampus }
$$

Virtual merupakan hasil praktek perkuliahan dari mahasiswa Program Studi Pendidikan Musik IAKN Manado semester lima tahun akademik 2020/2021 yang diselenggarakan pada 19 Desember 2020 lalu. Festival musik tersebut dilakukan secara daring dengan menampilkan 11 penyaji yang ditayangkan melalui aplikasi Zoom dan dapat di akses oleh masyarakat

\footnotetext{
${ }^{2}$ Wartakotatravel.com. Kafe dan restoran diimbau bantu musisi dengan menampilkan pertunjukan musik virtual. (10.Juli.2020)
} 
umum. Kegiatan tersebut terselenggara secara virtual yang diakhiri dengan diskusi ilmiah antara komposer dengan penonton. Secara profesionalitas pengelola Festival Musik Kampus Virtual merupakan merupakan mahasiswa yang tidak memiliki pengalaman mengelola pertunjukan virtual. Namun secara hasil penyajiannya dapat dikatakan cukup baik dan berhasil. Disini peneliti tertarik melihat bagaimana pengelolaan festival musik kampus virtual di IAKN Manado, dan apa kekurangan dan kelebihan pengelolaannya?

Seni pertunjukan merupakan sesuatu kegiatan seni yang dipertunjukan kepada sekumpulan orang. Sehingga seni pertunjukan merupakan sebuah bentuk karya seni yang esensinya harus dipertunjukan kepada masyarakat penonton. Seni pertunjukan tanpa hadirnya penonton akan menghilangkan esensi dari pertunjukan itu sendiri. Sehingga kehadiran penonton dalam sebuah pementasan seni pertunjukan merupakan hal mutlak dan sangat mendasar. Pada pertunjukan seni sang penyaji dan penonton akan membangun sebuah interaksi verbal, fisik, dan emosi. Seni pertunjukan

\footnotetext{
${ }^{3}$ Hadi, Sumandiyo, Seni pertunjukan dan masyarakat penonton, (Yogyakarta:2012)
}

memiliki unsur-unsur yang membentuk karakteristiknya sebagai pertunjukan yaitu pencipta seni, pelaku seni, produk seni, pengelola, dan pengamat, baik itu penonton ataupun kritikus ${ }^{3}$.

Kelima unsur-unsur tersebut yang akan membentuk sistem seni sebagai pertunjukan. Unsur-unsur tersebut saling terintegrasi secara aktif untuk menghidupkan organorgan seni pertunjukan. Pencipta seni merupakan sebagai penuang gagasan atau ide terciptanya sebuah karya seni yang diwujudkan oleh pelaku seni bisa sebagai aktor, musisi, atau penari. Gagasan tersebut belum dapat dikatakan sebuah produk seni pertunjukan ketika karya tersebut belum dipentaskan didepan penikmat seni (penonton). Kemudian hadirnya seni pertunjukan dalam sebuah pementasan tidak akan dapat terlaksana tanpa adanya pengelola. Pengelola merupakan suatu kelompok yang secara khusus bertugas mengatur pementasan yang diselenggarakan. Berdasarkan tugas tersebut pengelola akan secara langsung mengatur unsur-unsur manajemen yang terkandung dalam pementasan yaitu manusianya, 


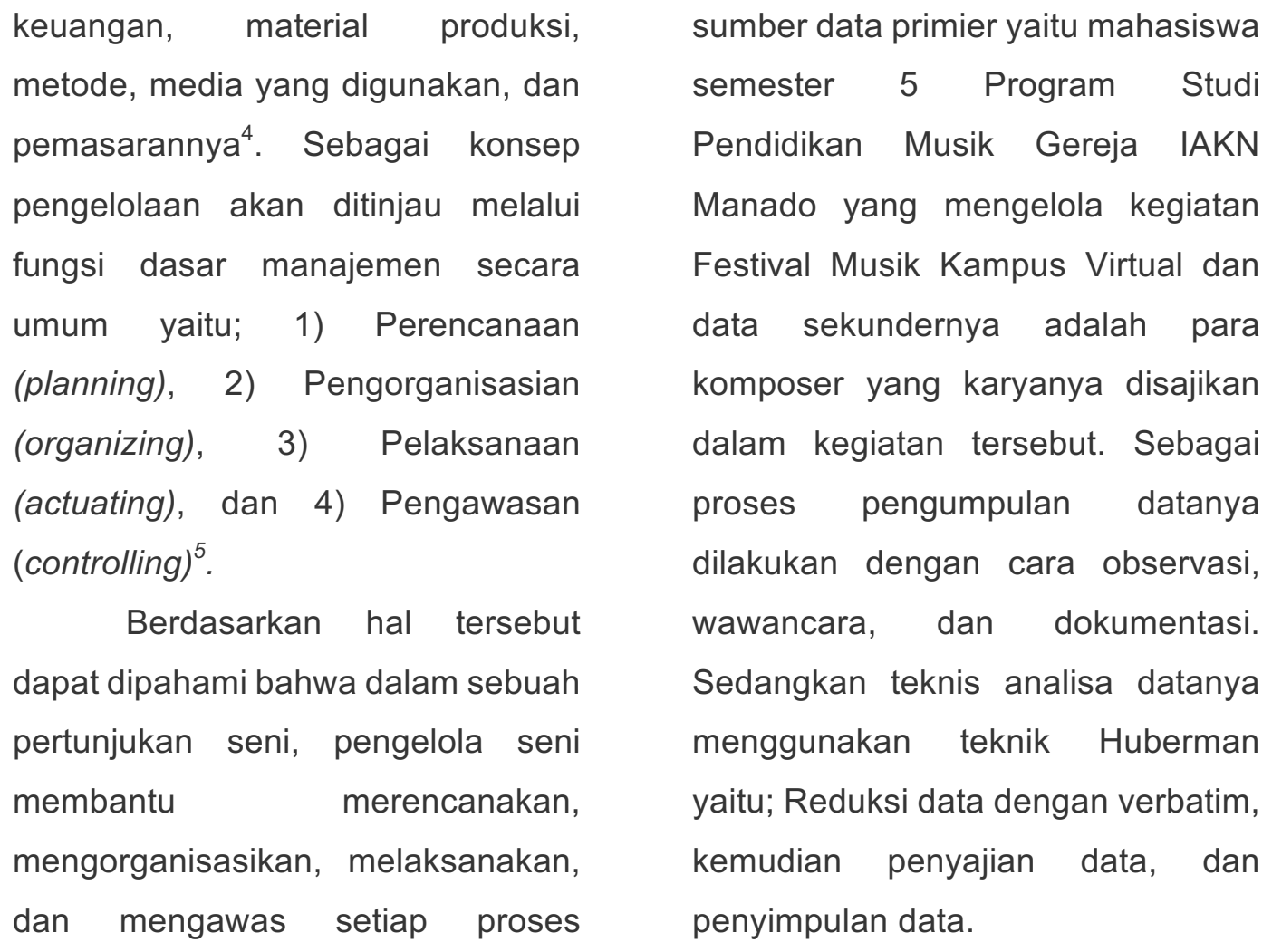

produksi pementasan yang meliputi penyusunan jadwal latihan, koordinasi pemain, pemilihan pementasan, artitsik, promosi, acara, pengelolaan penonton, pembiayaan produksi, dan sebagainya.

\section{Metode Penelitian}

Pada penelitian ini menggunakan metode kualitatif dengan lokus penelitian di Program Studi Pendidikan Musik Gereja IAKN Manado. Sedangkan teknik sampling yang digunakan adalah purposive sampling. Sumber data terdiri dari

\footnotetext{
4 Pojok Seni, Pengertian, Penerapan dan Tujuan Manajemen Pertunjukan Seni. (Pojok Seni: 2018)
}

\section{Hasil Penelitian dan Pembahasan}

\section{Hasil Penelitian \\ Pada penelitian ini peneliti menemukan bahwa proses pengelolaan Festival Musik Kampus Virtual dikelola berdasarkan dua kategori sifat pekerjaannya yaitu Artistik dan Non- Artistik. Dibawah ini tabel struktur tim produksi sesuai dengan kategori pekerjaanya:}

\footnotetext{
${ }^{5}$ Wijaya, Candra, Muhammad, Rifai. Dasardasar manajemen; mengoptimalkan pengelolaan organisasi secara efektif dan efesien.Perdana Publishing. (Medan:2016)
} 


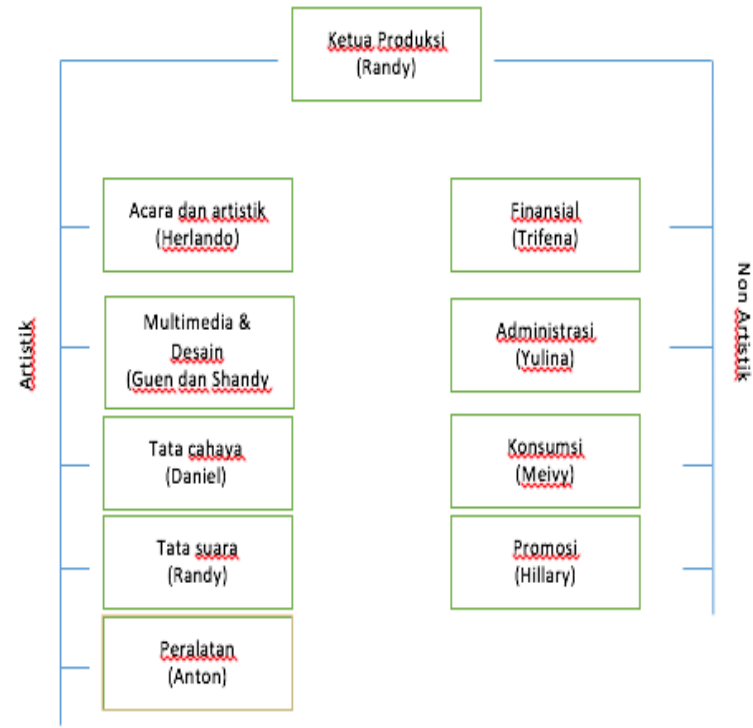

Gambar 1. Tim produksi Festival Musik Kampus Virtual

Pembentukan tim produksi dilakukan dengan rapat perencanaan melalui aplikasi Zoom Meeting. Setelah pembentukan tim produksi maka dilakukan pembahasan konsep bentuk kegiatan yang akan dikerjakan. Pertemuan ini juga dilakukan secara virtual yaitu melalui aplikasi Zoom Meeting. Pembahasan konsep acara meliputi tempat pelaksanaan penyelenggaran festival, waktu, dan tema kegiatan. Pada proses pembahasan ini cukup lama, karena pengelola bingung menentukan tempat yang sesuai dengan situasi dan kondisi kemampuan tim produksi dan penampil. Keputusan pertama kegiatan ini diselenggarakan di ruang terbuka di salah satu daerah perbukitan di Tomohon, Sulawesi
Utara dengan konsep Live streaming. Jadi kegiatan Festival Musik Kampus Virtual akan diselenggarakan secara live streaming di media Youtube. Setiap penyaji karya akan menampilkan karyanya dan ditayangan secara langsung. Namun setelah tiga minggu keputusan ini disepakati, banyak menemukan kendala yaitu; peraturan baru pemerintah yang melarang perkumpulan orang banyak di setiap daerah, karena peningkatan status Provinsi Sulawesi Utara yang sebelumnya zona kuning menjadi merah. Sehingga tidak mungkin diselenggarakan di ruang terbuka. Kemudian kendala pada jaringan internet yang sulit dijangkau pada lokasi yang dituju. Sehingga berdasarkan diskusi yang cukup lama, maka penyelenggaraan kegiatan festival tersebut dilakukan di Kampus, dengan sistem setiap penampil akan merekam video dan audionya terlebih dahulu kemudian pada hari penyelenggaraan akan ditampilkan pada hari sabtu tanggal 19 Desember 2020 pukul 19.00 Wita yang disiarkan melalui Youtube dan Aplikasi Zoom.

$$
\text { Berdasarkan pembagian }
$$
tugas tim produksi secara fungsional manajemen maka sistem pekerjaan tersebut seperti berikut: 


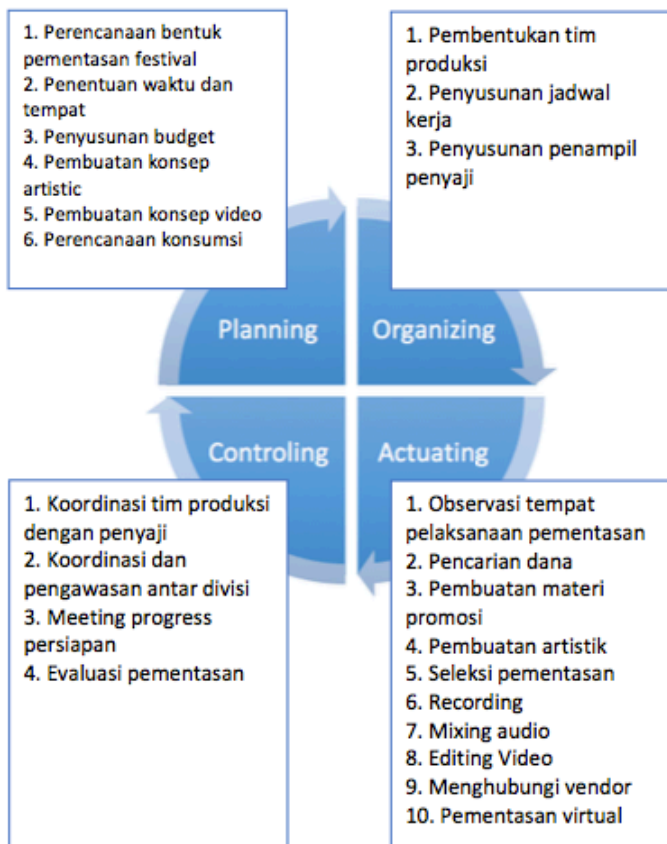

Gambar 2. Sistem kerja produksi berdasarkan POAC

Empat pembagian kerja tersebut yaitu Pertama; Perencanaan, setelah penentuan konsep dasar penyelenggaraan festival maka setiap divisi tim produksi mulai merencanakan konsep dasarnya masing-masing. Artinya setiap divisi akan menyusun bentuk dan cara pelaksanaan konsep yang akan mereka kerjakan kepada ketua produksi sebelum disetujui. Beberapa hal perencanaan yang dilakukan adalah perencanaan artistik, perencanaan biaya yang dibutuhkan, perencanaan rekaman audio, perencanaan konsep video dan penayangannya, perencanaan konsumsi, dan perencanaan susunan acaranya. Setiap perencanaan dilakukan secara virtual yaitu melalui aplikasi Zoom. Namun ada beberapa divisi yang melakukan pembahasan melalui pertemuan langsung yaitu disaat penyusunan konsep video dan penayangannya serta divisi artistik. Hal tersebut dilakukan menurut ketua divisi Multimedia dan Artistik dikarenakan keterbatasan mereka menguasai software yang akan digunakan dalam proses editing maupun penayangan seluruh video penampil. Software yang digunakan adalah OBS dan Final cut pro. Jadi menurut mereka untuk menyusun perencanaan video harus mengetahui dulu alat dan software yang akan digunakan supaya sistem kerjanya bisa lebih mudah.

Kemudian tahap kedua adalah penggorganisasian; pada tahap ini setiap divisi akan membentuk tim produksi mereka masing-masing dengan melibatkan mahasiswa junior melalui aplikasi Zoom. Setelah itu penyusunan jadwal kerja tim yang dilakukan juga melalui virtual.

Tahap ketiga adalah pelaksanaan; dimana setiap divisi bekerja mewujudkan setiap konsep yang sudah disepakati bersama tim produksi. Peneliti melihat beberapa 
urutan pekerjaan yang dapat dideskripsikan selama tahap pelaksanaan adalah sebagai berikut; pencarian dana, dimana proses pencarian dana dilakukan selama 2 bulan sebelum pelaksanaan festival dengan cara ngamen, kartu teman. Kartu teman yaitu dimana tim keuangan akan memberikan selembar kartu donatur kepada seluruh elemen kampus dimulai dari mahasiswa, dosen, dan pegawai yang nantinya sang penerima kartu akan memberikan sejumlah uang sesuai kemampuannya. Kegiatan tersebut dilakukan dengan tatap muka, artinya dilakukan secara langsung.

Kemudian proses pembuatan materi promosi, materi promosi dilakukan secara virtual. Artinya pembuat materi video promosi bekerja dirumah, kemudian setelah selesai, materi tersebut akan dikirim melalui aplikasi Telegram yang dimana seluruh tim produksi dapat mengakses dan mengkoreksi bagian video yang perlu diperbaiki. Pada proses selanjutnya adalah seleksi para penampil yang dilakukan secara tatap muka dengan dosen pengampuh. Namun ada beberapa penampil yang mengikuti seleksi dengan mengirimkan videonya karena beberapa kendala seperti jarak rumah yang sangat jauh, sakit, dan tim pemusik yang belum siap sehingga harus menggunakan sistem daring. Setelah tahap seleksi maka dilakukan tahap rekaman secara audio maupun video. Proses ini dilakukan di laboratorium musik. Jadi setiap para penampil akan bergantian memasuki studio rekaman. Peneliti melihat setiap para penampil yang hadir pada proses rekaman wajib menggunakan masker guna mengikuti protokol kesehatan. Proses rekaman video dilakukan secara bersamaan pada saat rekaman audio berjalan. Sebanyak 11 penampil yang direkam diselesaikan pada pukul 23.00 Wita, dimana proses ini dimulai pada pukul 13.00 Wita.

Setelah proses rekaman dilakukan maka akan dilakukan proses edit video dan mixing audio. Proses edit video tidak dapat dilakukan apabila audio belum selesai di mixing. Proses mixing terselesaikan selama satu hari setelah proses rekaman dilakukan. Setelah proses mixing maka dilanjutkan proses editing video dari 11 penampil dengan menggunakan software Filmora dan Final cut pro. Peneliti mengamati proses editing video memakan waktu cukup lama karena tim yang bertanggungjawab 
pada divisi ini tidak menguasai software tersebut sehingga butuh proses mempelajari kembali. Namun karena terdesak waktu maka tim pengelola mendatangkan pihak yang mampu menguasai software Filmora dan Final cut pro untuk mengedit seluruh video. Proses ini memakan waktu tiga hari lamanya, atau satu hari sebelum penyelanggaraannya. Setelah seluruh video selesai di edit maka disusun urutan penampilan berdasarkan bentuk karya musiknya. Satu hari sebelum penyelenggaraan seluruh video yang sudah selesai di edit akan dikoreksi oleh ketua produksi melalui aplikasi Telegram. Setelah ketua menyetujuinya maka tim multimedia menyiapkan seluruh peralatan dan kebutuhan yang akan digunakan untuk penyelenggaraan virtual. Konsep penyelenggaraanya yaitu seluruh penonton akan diundang melalui link Aplikasi Zoom atau dapat melihat melalui Youtube. Penyelenggaraan akan ditayangkan secara langsung, dimana pembawa acara akan menuntun rangkaian seluruh acara Festival Musik Kampus Virtual secara langsung namun sebelas karya ditampilkan melalui hasil rekaman video yang sudah disusun sesuai urutannya. Namun 2 jam sebelum penyelenggaraan tim multimedia belum berhasil mengkonfigurasikan sistem pada software OBS yang di sinkornkan dengan Youtube dan Zoom. Sehingga karena persoalan teknis maka siaran melalui Youtube di batalkan, jadi penyelenggaraan Festival Musik Kampus Virtual hanya digunakan melalui aplikasi Zoom saja.

Selama penayangan Festival Musik Kampus Virtual seluruh rangkaian acara berjalan dengan lancar namun pada pertengahan acara jaringan internet kurang stabil sehingga membuat tampilan terputus-putus. Namun hal tersebut dapat diatasi sehingga kegiatan dapat kembali berjalan dengan baik. Setelah seluruh penampil sudah di tayangkan, kegiatan Festival Musik Kampus Virtual dilanjut dengan diskusi antara penyaji dengan para penonton dan dosen. Sesi ini tidak lama hanya berlangung 30 menit. Setelah sesi diskusi maka kegiatan Festival Musik Kampus Virtual berakhir dengan penampilan video penutup. Setelah penyelenggaraan berakhir

Selanjutnya tahap keempat, Pengawasan; dimana seluruh tim produksi melakukan rapat evaluasi terbatas, yang berlangsung selama 30 menit dengan tatap muka secara 
langsung. Adapun tahapan demi tahapan dapat dilakukan tanpa berurutan. Artinya pada saat tahap perencanaan maupun tahap pelaksanaan, tahap pengawasan dapat dilakukan.

\section{Pembahasan}

Berdasarkan hasil penelitian tersebut peneliti menganalisis bahwa sistem pengelolaan yang diterapkan menggunakan pola seperti tabel dibawah ini:

\begin{tabular}{|l|l|}
\hline \multicolumn{2}{|c|}{ Planning } \\
\hline \multicolumn{1}{|c|}{ Tatap muka melalui Zoom } & Tatap muka melalui pertemuan di ruangan \\
\hline 1. Perencanaan bentuk pementasan & 1. Pembuatan konsep video \\
\hline 2. Penyusunan budget & 2. Pembuatan konsep artistik \\
\hline 3. Perencanaan konsumsi & \\
\hline 4. Penentuan waktu dan tempat & \\
\hline
\end{tabular}
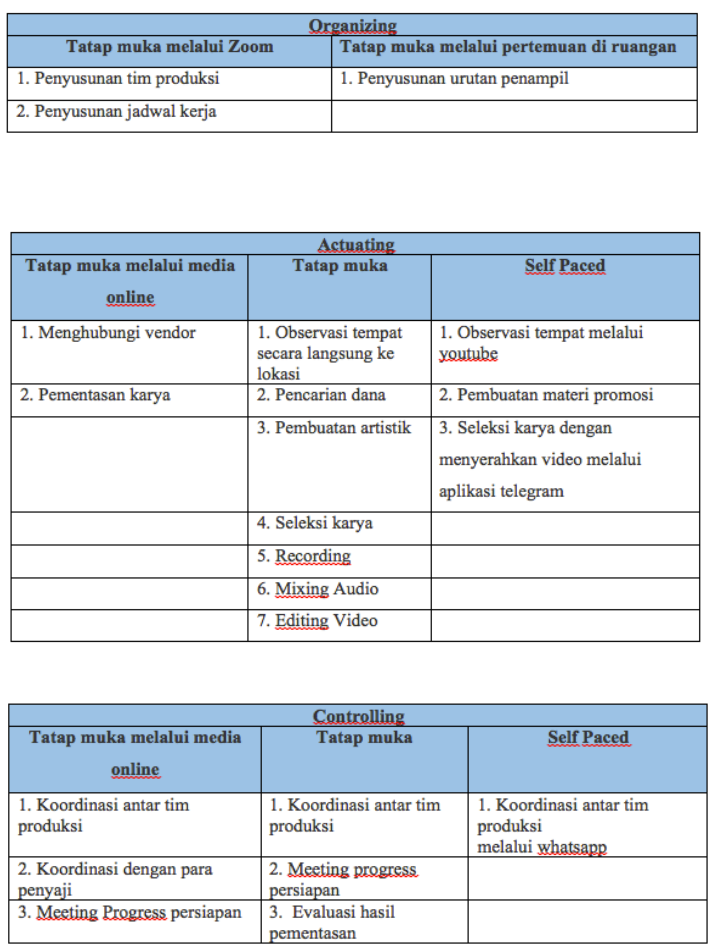

dengan kemampuan sumber daya yang ada, sifat pekerjaannya apakah memang

mengharuskan membutuhkan tatap muka secara langsung atau dapat dilakukan secara luring. Kemudian proses pengelolaannya juga berjalan berdasarkan 4 fungsi manajemen umum yaitu proses perencanaan, pengorganisasian, pelaksanaan, dan pengawasan. Pengelolaan yang diterapkan banyak menggunakan teknologi digital virtual. Aplikasi dan software serta jaringan internet menjadi media utama keberhasilan kegiatan ini. Namun hal tersebut tidak dapat berjalan dengan baik apabila tidak ada sumber daya manusia yang memadai untuk menggunakan seluruh teknologi tersebut. Bahkan berdasarkan hasil penelitian ditemukan bahwa banyak perencanaan yang berjalan tidak sesuai dengan jadwal. Banyak waktu yang terbuang hanya untuk mempelajari media teknologi yang digunakan. Hal ini menunjukkan bahwa seharusnya teknologi digital virtual mampu membuat efesiensi dan produktifitas pekerjaan semakin baik akan tidak dapat berjalan karena sumber daya manusianya tidak mampu menguasai teknologi tersebut. Hal ini menjadi salah satu kekurangan dari sistem pengelolaan Festival Musik Kampus Virtual.

Namun melalui sistem 
pengelolaan yang digunakan mereka mampu menghemat biaya produksi hampir $50 \%$ dari total anggaran produksi yang dianggarkan. Kemudian pengelola pertunjukan virtual ini juga tidak sulit untuk mencari penonton. Jumlah penonton yang hadir pada saat itu adalah 65 orang. Hal ini menunjukkan bahwa tidak perlu biaya yang mahal, dan tidak perlu waktu yang lama, media virtual sangat efektif dan mudah mencari penonton daripada pertunjukan yang konvensional. Kedua hal ini menjadi kelebihan dari sistem pengelolaan yang diterapkan.

\section{Kesimpulan}

Berdasarkan data dari hasil penelitian tersebut maka dapat disimpulkan bahwa sistem pengelolaan yang digunakan pada Festival Musik Kampus Virtual di IAKN Manado menggunakan sistem Blended Methode yang menerapkan cara tatap muka secara langsung, tatap muka melalui media online, dan komunikasi melalui media sosial tanpa tatap muka. Kemudian penggunaan metode tersebut belum dapat berjalan dengan maksimal secara waktu karena kemampuan sumber daya manusianya yang kurang menguasai teknologi. Pengelolaan dengan menggunakan media virtual harus didukung dengan kemampuan sumber daya manusia yang paham, terbiasa, dan menguasai media teknologi digital secara virtual.

\section{Daftar Pustaka}

Aurima. 2018. Strategi pengelolaan organisasi Cicilia Ballet School di Jakarta Barat. Yogyakarta

Bryan, A, KN Volchenkova. 2018. Blended Learning: Defenition, Models, Implications for Higher Education. Soul Ural State University, C helyabinsk, Russian Federation. Rusia

Hadi, Y. Sumandiyo. 2021. Seni Pertunjukan dan Masyarakat Penonton, Yogyakarta: BP ISI Yogyakarta.

Sianturi, Erwin. 2020. New Normal: Dimensi Percepatan Menuju Peradaban Musik 4.0. Lampung. Pusaka Media.

Suganda, dadang. 2002. Manajemen Seni Pertunjukan. Bandung. STSI Press, 2002.

Suka Hardjana, Dieter Mack, Joko S Gombloh, haryo Suyoto, Remy Silado. 1995. Seni Pertunjukan Indonesia. Yogyakarta. Seni Pertunjukan Indonesia.

Robbins, Coulter. 2007. Manajemen, edisi kedelapan, jilid 2. Jakarta. Indeks.

Pojok Seni. 2018. Pengertian, Penerapan, dan Tujuan Manajemen Pertunjukan Seni. Pojok Seni.

Wartakotatravel.com. 2020. Kafe dan Restoran diimbau bantu musisi dengan menampilkan pertunjukan musik virtual.

Wijaya, Candra, Muhamad, Rifai. 2016.

Dasar-dasar 
Clef: Jurnal Musik dan Pendidikan Musik| Vol. I| No. 2 | Hal. 13-23

EISSN: $2746-7473$

manajemen: mengoptimalkan

pengelolaan organisasi secara

efektif dan efesien. Medan.

Perdana publshing. 